\title{
Blurred Identity in Pandemic Time: Humanity Response toward Covid in Social Media
}

\author{
Misbah Zulfa Elizabeth \\ \{zulfa_elizabeth@walisongo.ac.id\} \\ Faculty of Social Science State Islamic University Walisongo
}

\begin{abstract}
The pandemic has resulted in various changes, including those related to identity. Identity is an expression that involves various characteristics of the self, both related to the self personally and related to genealogy, groups, and demographic structures. Applying qualitative research and a media approach, this study tries to examine: 1 . How is the expression of humanity related to covid-19 on social media; 2 . What is the reaction to that expression?; 3 . Why did the reactions occured. The results indicated that social media take part in disseminating information related to the need of anyone infected by Covid-19; the emergence of Covid-19 has raised humanitarian awareness that is not based on initial identity. What emerges is a borderless identity; they show concern because of their empathy for the suffering of others infected with Covid-19. With this data, it appears that the identity that limits a person can disappear due to the pandemic conditions
\end{abstract}

Keywords: Identity; Covid-19; Humanity Response; Social Media

\section{Introduction}

The Covid-19 pandemic is actually a health issue. Starting with fever symptoms and spreading rapidly among the people of Wuhan, this health problem quickly spread throughout the world (Li, T., et.al., 2020). Because this health problem is a pandemic, its impact has spread to all social processes, both tangible and non-tangible (Thoresen, S., et al., 2021). Tangible social processes include processes that involve interactions and transactions, for example social and economic relationships, while non-tangible ones are related to values, knowledge, and beliefs (Elizabeth, 2021, Sommerlad, A. et. al.,2021; Thoresen, S., et al., 2021). Tangible social processes might be observed because they have to do with activities, meanwhile non-tangible processes have to do with unobserved things. Although tangible and non-tangible social processes cannot be separated discretely, but at least the separation describes two different but inseparable social realities.

One of the intangible social processes that has changed during this pandemic is identity. Due to the massive number of community members who have been exposed to the Covid-19 virus, there has been massive awareness about the importance of helping each other for those exposed to Covid-19. The spirit of help that became the focus of this research was when it was found that convalence plasma gave great hope for the cure of Covid 19. When this information spread, and there was an increase in the number of Covid 19 sufferers, the media became an 
intermediary for the dissemination of information about the need for convalescent plasma to the public. People no longer see who is being exposed, the important thing is that they respond quickly in order to help others.

Many studies on Covid have been carried out by experts. In general, beside the focus on medical,the tendency of studies on Covid is related to: firstly economy as studied by Açikgöz, Ö. and Günay, A. (2020) who focused on the context of Turkish economy; Dev, S.M. and Sengupta, R., (2020)in the context of Indian economy; Forsythe, E. (2020) who focused on labor market flow on the context of Covid 19 pandemic, and Susilawati, S., (2020)who studied the impact of Covid 19 pandemy on Indonesian economy. Secondly, the social relations as studied by Sommerlad, A. et. al.,2021; Thoresen, S., et al., (2021) ; Philpot, L.M., et.al., 2021; and thirdly, education as studied by Teräs, M.et. al., (2020). Dreesen, T., et. al, (2020); and Lathabhavan, R. and Griffiths, M., (2020). Studies on Covid that are linked to identity are still limited.

On the above logic, this study is oriented to the studies that link Covid-19 with identity changes. The assumptions of this study are: First, social media uses media symbols in conveying information so that they are able to influence the ideas, attitudes, and actions of readers. Second, social relationships and caring are built up due to the common severe conditions of the pandemic experienced by human beings; Third, local value of help needs a stimulant to regenerate. Based on the logic and assumptions, this research has the purposes to explore:1. How is the expression of humanity related to covid-19 on social media; 2 . What is the reaction to that expression?; 3 . Why did the reaction occur.

\section{Theoretical Framework}

\subsection{Identity}

In social identity theory, a social identity is a person's knowledge that he or she belongs to a social category or group (Hogg and Abrams 1988). A social group is a set of individuals who hold a common social identification or view themselves as members of the same social category. Through a social comparison process, persons who are similar to the self are categorized with the self and are labeled the in-group; persons who differ from the self are categorized as the out- group. In early work, social identity included the emotional, evaluative, and other psychological correlates of in-group classification (Turner et al. 1987). Two important processes involved in social identity formation, namely self-catego- rization and social comparison, produce different consequences (Hogg and Abrams, 1988).

The consequence of self-categorization is an accentuation of the perceived similarities between the self and other in-group members, and an accentuation of the perceived differences between the self and out- group members (Turner et al. 1987). This accentuation occurs for all the attitudes, beliefs and values, affective reactions, behavioral norms, styles of speech, and other properties that are believed to be correlated with the relevant intergroup categorization. The consequence of the social comparison process is the selective application of the accentuation effect, primarily to those dimensions that will result in self- enhancing outcomes for the self. Specifically, one' s self-esteem is enhanced by evaluating the in-group and the out-group on dimensions that lead the in-group to be judged positively and the out-group to be judged negatively (Suls, J.M. and Miller, R.L., 1977). 


\subsection{Humanity and Humanitarian}

The terms of humanity and humanitarian are closely related terms. Humanity refers to the understanding of humans as a unified human community, while humanitarian refers to actions to overcome human suffering (Barnett, M., 2011). Humanity is thought of as an aggregate entity. Humanitarian expertise considers "persons in need" to be individuals who are autonomous, independent, and interchangeable. Thus, it bypasses institutions and tends to "depoliticize the issues of power (Fassin, D., 2011). Humanitarian means helping people who are suffering and saving lives any time any place in the world. Humanitarian work requires being responsible, conscious of the circumstances of other people's lives, and helping them on the basis of need, without discrimination (Weiss, T.G., 2016).

Based on the experiences of human beings in various parts of the world, the suffering as a result of various disasters rise to humanitarian movements in various forms, both institutional and invidual This kind of spirit and movement is generally referred to as humanitarianism (Walker, P., 2014). This movement activated the belief in the value of human life, whereby humans practice benevolent treatment and provide assistance to other humans to reduce suffering and improve the conditions of humanity for moral, altruistic, and logical reasons (Meron, T., 1989).

\subsection{Covid-19 Pandemic}

Covid-19 first appeared in Wuhan, China at the end of 2019 as a fact about health problems in the form of infections caused by viruses that attack the respiratory tract (Shi, Y. Et al., 2020). This virus is very easy to spread and grow and cause severe infectious effects and even lead to death (Li, T., Lu, H. and Zhang, W., 2020.). Various medical efforts were made by experts but the development of this virus was so fast that it became a pandemic (Chen, L., 2020.). The latest development at the time of the development of the pandemic was the discovery of a Covid 19 treatment using convalescent plasma. In a medical experiment, it was found that treatment using convalence plasma has promising effectiveness, so it is recommended in the effort to treat Covid-19 infection (Roback, J.D. and Guarner, J., 2020). apart from efforts to increase endurance by using vaccines (Graham, B.S., 2020). With this in mind, efforts to deal with Covid 19 must involve handling and prevention efforts.

\section{Methodology}

This is a qualitative research, with a field study approach taking the focus on social media platform of Whatsapp. The primary data of this research are: 1). Information about the need of aid of convalence plasma for Covid 19 patients launched in Whattapp platform media. 2). Interview with the patient family and the person giving the aid of convalence-plasma, and 3) Document contained the information about convalence plasma treatment for Covid 19 patients. Data about the expression of the media were analyzed using media and content analysis to understand the content and meaning. The data obtained from the informants were analyzed by identifying information about the origin of plasma donors for their families to see how social identity determines the decision to become a donor. This data forms the basis for an analysis of identity in a particular context 


\section{Result and Discussion}

The expression of humanity related to covid-19 on social media.

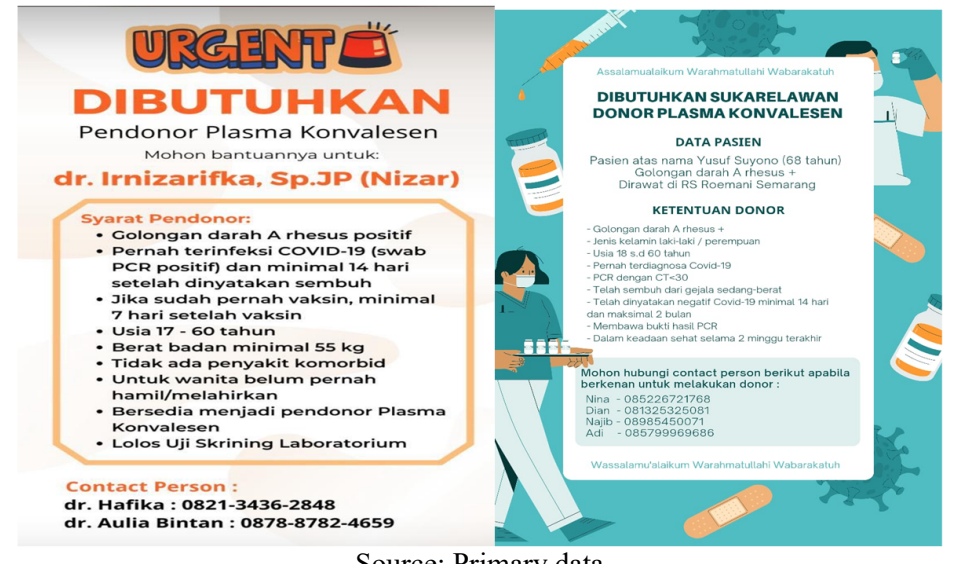

Source: Primary data

Fig. 1. Flyer style information
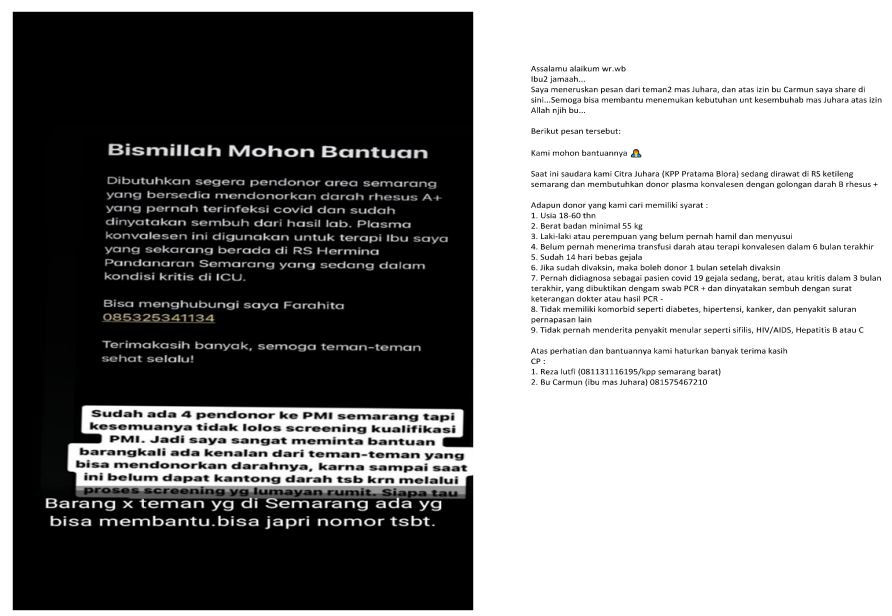

Source: Primary data

Fig. 2. Descriptive style information

It can be seen in the expression of delivering information regarding the need for blood plasma to help Covid-19 sufferers by using simple descriptions and with certain designs. It appears in the two expressions that the message conveyed involves several things: first, the message about the need for blood plasma; second, data of the patients, third, regarding donor prerequisites; fourth, information on screening for donors by mentioning authoritative institutions, namely the Indonesian Red Cross; fifth, mention the contact number. Looking at the exposure structure of the information regarding the need for blood plasma assistance for people with Covid-19, it appears that the structure used is a complete information and 
communication structure. As stated by Mehrabian (2017a) that the structure of information in communication includes elements of the sender, the message conveyed, an explanation of the message, and the object of the message. With a complete structure in the communication information, the information conveyed invites the attention of those who receive the message to give their response. This relates to the message response put forward by Mortensen, C.D. ed., (2017) and Mehrabian (2017b) that the communication flow that carries the message will bring a response according to the content of the message. In this context, the messenger only conveys the message with the name and contact number information, without any information about the social circle of the messenger or those who need help.

\section{a) The Reaction to that Expression}

Some reactions from message recipients on the Whatsapp platform found in this study include: first, confirming the sender of the message by asking what the social relationship with the sufferer or the sender of the message was, and then spreading the message; and secondly they immediately spread the information to several Wattsap groups; and thirdly, call the contact number listed to open the possibility of providing the needed assistance if the prerequisites are met. The data obtained from the informants indicated that although the blood type is in accordance with the requirements, it does not necessarily meet the medical requirements. For example related to blood pressure or other medical conditions. Informants from the patient's family also stated that some of the potential donors who expressed their willingness to become donors and came directly to the Indonesian Red Cross were not people they knew. They came and prepared themselves to donate blood because of the call of humanitarian feeling. Referring to Barthes (1981) also Elizabeth (2017) as a visual image, the messages have two elements, studium and punctum. Studium refers to the cultural, linguistic, and political interpretation of a photographic work while punctum refers to touching details, which emphasize a direct relationship to the object or person in it. The punctum here is the information within the flyer, meanwhile, the studium is the meaning of the reality that is expressed behind the flyer. The pandemic context, the need of care and help, the effort to minimize the rate of mortality because of Covid-19 pandemic is the reality behind the text that stimulate persons to react.

\section{b) The Reasons of the Reaction}

The willingness of people to disseminate information regarding the need for blood plasma from Covid-19 patients to several WhatsApp groups as well as the willingness to become blood donors is based on religious and humanitarian reasons. One of the donor told that she spontaneously response the information she received without considering who needs the blood. This data has shown a change in identity bonds in the context of this pandemic. In the pre-pandemic period, usually the need for blood donations was conveyed to the closest people, both in genealogical relationships and other social relations. However, in a pandemic situation people feel more called to provide assistance without considering the predominant ties in the past. The results indicated that social media take part in disseminating information related to the need of anyone infected by Covid-19; the emergence of Covid-19 has raised humanitarian awareness that is not based on initial identity. What emerges is a borderless identity; they show concern because of their empathy for the suffering of others infected with Covid-19. With this data, it appears that the identity that limits a person can disappear due to the pandemic conditions. 


\section{Conclusion}

Overall, there is a change in our society There has been a change in society related to caring for others during the Covid pandemic. Because of the power of the media, people no longer consider their identity, and only focus their attention on helping others. In this context there is a paradox regarding the impact of the media. On the one hand, social media is seen as having distanced social relations between individuals, on the other hand, it has the power to bind the fabric of humanity and stimulate the humanitarian movement

\section{References}

[1] Açikgöz, Ö. and Günay, A., 2020. The early impact of the Covid-19 pandemic on the global and Turkish economy. Turkish journal of medical sciences, 50(SI-1), pp.520526.

[2] Barnett, M., 2011. Empire of humanity. Cornell University Press.

[3] Barthes, Roland. 1981. Camera Lucida.New York: Hill and Wang.

[4] Chen, L., Xiong, J., Bao, L. and Shi, Y., 2020. Convalescent plasma as a potential therapy for

[5] COVID-19. The Lancet infectious diseases, 20(4), pp.398-400.

[6] Dev, S.M. and Sengupta, R., 2020. Covid-19: Impact on the Indian economy. Indira Gandhi Institute of Development Research, Mumbai April.

[7] Dreesen, T., Akseer, S., Brossard, M., Dewan, P., Giraldo, J.P., Kamei, A., Mizunoya, S. and Ortiz, J.S., 2020. Promising practices for equitable remote learning: Emerging lessons from COVID-19 education responses in 127 countries.

[8] Elizabeth, M. 2017. "Perlawanan Visual Perempuan dalam Poster". JSW (Jurnal Sosiologi Walisongo), 1(2), 147-160. doi:http://dx.doi.org/10.21580/jsw.2017.1.2.1987

[9] Elizabeth, M., 2021. "Covid-19, Knowledge System and Womenpreneurship" The Pandemic: A Leap of Faith, Yogyakarta: Bildung, 321-329

[10] Fassin, D., 2011. Humanitarian reason. University of California Press.

[11] Forsythe, E. (2020). Labor market flows and the Covid-19 economy. Available at SSRN 3586074.

[12] Graham, B.S., 2020. Rapid COVID-19 vaccine development. Science, 368(6494), pp.945-946.

[13] Hogg, M.A. and Abrams, D., 1988. Social identifications: A social psychology of intergroup relations and group processes. Taylor \& Frances/Routledge.

[14] Lathabhavan, R. and Griffiths, M., 2020. First case of student suicide in India due to the COVID-19 education crisis: A brief report and preventive measures. Asian journal of psychiatry, 53, p.102202.

[15] Li, T., Lu, H. and Zhang, W., 2020. Clinical observation and management of COVID19 patients. Emerging microbes \& infections, 9(1), pp.687-690.

[16] Mehrabian, A., 2017a. Communication without words. In Communication theory (pp. 193-200). Routledge.

[17] Mehrabian, A., 2017b. Nonverbal communication. Routledge.

[18] Meron, T., 1989. Human rights and humanitarian norms as customary law (p. 82). Oxford: Clarendon Press.

[19] Mortensen, C.D. ed., 2017. Communication theory. Routledge. 
[20] Philpot, L.M., Ramar, P., Roellinger, D.L., Barry, B.A., Sharma, P. and Ebbert, J.O., 2021. Changes in social relationships during an initial "stay-at-home" phase of the COVID-19 pandemic: A longitudinal survey study in the US. Social Science \& Medicine, 274, p.113779.

[21] Roback, J.D. and Guarner, J., 2020. Convalescent plasma to treat COVID-19: possibilities and challenges. Jama, 323(16), pp.1561-1562.

[22] Shi, Y., Wang, G., Cai, X.P., Deng, J.W., Zheng, L., Zhu, H.H., Zheng, M., Yang, B. and Chen, Z., 2020. An overview of COVID-19. Journal of Zhejiang UniversitySCIENCE B, 21(5), pp.343-360.

[23] Sommerlad, A., Marston, L., Huntley, J., Livingston, G., Lewis, G., Steptoe, A. and Fancourt, D., 2021. Social relationships and depression during the COVID-19 lockdown: longitudinal analysis of the COVID-19 Social Study. Psychological medicine, pp.1-10.

[24] Suls, J.M. and Miller, R.L., 1977. Social comparison processes: Theoretical and empirical perspectives. Hemisphere.

[25] Susilawati, S., Falefi, R. and Purwoko, A., 2020. Impact of COVID-19's Pandemic on the Economy of Indonesia. Budapest International Research and Critics Institute (BIRCI-Journal): Humanities and Social Sciences, 3(2), pp.1147-1156.

[26] Teräs, M., Suoranta, J., Teräs, H. and Curcher, M., 2020. Post-Covid-19 education and education technology 'solutionism': A seller's market. Postdigital Science and Education, 2(3), pp.863-878.

[27] Thoresen, S., Blix, I., Wentzel-Larsen, T. and Birkeland, M.S., 2021. Trust and social relationships in times of the COVID-19 pandemic. European Journal of Psychotraumatology, 12(sup1), p.1866418.

[28] Turner, J.C., Hogg, M.A., Oakes, P.J., Reicher, S.D. and Wetherell, M.S., 1987. Rediscovering the social group: A self-categorization theory. Basil Blackwell.

[29] Walker, P., 2014. Shaping the humanitarian world. Routledge.

[30] Weiss, T.G., 2016. Humanitarian intervention. John Wiley \& Sons. 